RESEARCH ARTICLE

\title{
HOW GREEN MARKETING TOOLS SHAPE CONSUMER PURCHASE BEHAVIOR
}

\author{
Sandeepani DMM* and Samaraweera GC \\ Department of Agricultural Economics, Faculty of Agriculture, University of Ruhuna, \\ Kamburupitiya, Sri Lanka
}

Received: 2021.06.30, Accepted: 2021.09.05

\begin{abstract}
Consumers have more concerned about the 'green concept' and thus lead the industry to focus on 'green marketing' with the rapid increase in environmental and health considerations. In the Asian context, the studies on green marketing are still in their initial stages and more research is needed to gain its full potential within the market. As green marketing has become a novel and emerging concept in the Sri Lankan market, the present study focused to identify the consumer awareness and attitude towards green products while evaluating the consumer perception towards selected green marketing tools; eco-labelling, eco-branding and eco-packaging. A questionnaire survey was conducted among 150 randomly selected residents in Mapalana Magin Pahala Grama Niladari Division. Results indicated that the female consumers were willing to pay a premium price for green products to conserve the environment. Multiple linear regression analysis revealed that the income and education level have a highly significant contributions towards the consumers' purchase intention towards green products and the majority $(82.7 \%)$ and used the products promoted by green marketing $(52 \%)$ due to their high quality. Furthermore, the results of independent sample t-test revealed that the gender significantly shapes eco-labelling, eco-branding and eco-packaging attributes on consumer purchase behaviour. Hence, the findings will be instrumental for marketers and policymakers for the effective implementation of green marketing tools while considering gender and other attributes in particular.
\end{abstract}

Keywords: Green marketing, Green products, Purchase behavior

\section{INTRODUCTION}

With globalization, the whole world has to tackle environmental pollution and the vast destruction of natural resources due to industrialization, rapid technological development and diversification of human needs. Therefore, consumers are becoming socially responsible today by concerning more about the environment (Boztepe 2011). Accordingly, green consumers always believe that individual consumer can provide their contribution to the environmental protection process effectively while consuming healthy products or services. As the environmental problems becoming more prominent for people, organizations within the industry have started to focus their production in an environmentally friendly manner and thus

*Corresponding author: madusha0906@gmail.com moving to the "Green marketing" concept by adopting green policies in their production, pricing, promotion and distribution activities. Even though the companies primarily working for short-term profitability, they regulate strategies to achieve sustainability with the scope of long-term profitability, social wellbeing and environmental protection (Boztepe 2011).

In simply, marketing refers to "working in the market", to satisfy the consumers' needs at large. But the green marketing is not only providing consumers need but conserving the ecosystem and preventing environmental damages that caused by industrialized advancements (Rahman et al. 2017). Due to the higher perception of consumers towards the green concept, green marketing has 
emerged as a competitive strategy within the respective industry. Even though it has a high initial investment, it ensures long-term growth and profitability thus increases employee morale by working in a profitable and environmentally responsible organization (Saini 2013). The green marketing concept has become a revolution in the world of marketing and it describes the strategies used by a company to advertise the environmental sustainability of their products and consists of product modification, manufacturing, packaging, pricing, advertising and thus creating demand by utilizing eco-labelling, eco -branding and eco-packaging as green marketing tools. It focuses to accomplish customers' needs in a way that has the least harmful impacts on the environment (Farzin et al. 2020). According to the three phases of green marketing, "ecological marketing" makes attention to the ecological problems and solutions, "environmental marketing" focuses to reduce the environmental problems by utilizing innovative ideas, new design and technology and "sustainable marketing" considers the sustainable issues (Peattie 2001). The 4 P's of green marketing have an innovative style by developing products through an ecological manner, charging a premium price for improved performance, design and function etc., promoting the green concept, addressing a relationship with the biophysical environment and advertising the present corporate image of environmental responsibility and ensuring the green products are accessible to the customers (Roy 2013).

Among the green marketing tools, ecolabelling plays an important role as it helps to recognize the green products within the market. It is used as a symbol to show that the product is environmentally preferable and can be considered a green product (Simi 2009). Ecolabelling is a voluntary certification and labelling process for environmental performance that is practiced around the world (Global Ecolabelling Network 2020). It functioning as a communication tool, building trust, reflecting the image of products, enhancing customer awareness and knowledge and thus increase the purchase intention of consumers (Sharma and Kushwaha 2019).
Furthermore, eco-labelling has attempted to achieve the organizational objectives by balancing the consumers' purchasing behaviour and environmental protection (The Eco-Safe Blog 2020). From the global perspective, the consumption report of the EU found that $10 \%$ of the consumers in Europe consider the ecological product labels on the products that are sold in the supermarkets (Boztepe 2011). Eco-branding is a name, sign, term, design or symbol intended to identify environmentally friendly goods or services and thus differentiate them from nongreen products (Rahbar and Wahid 2011). When considering western countries, consumers in the USA and Germany have a positive action on eco-branded products such as green energy and body shops etc. (Wustenhagen and Bilharz 2006). Ecopackaging is an effective marketing tool to promote green products while enhancing purchasing behaviour of customers. It has a positive relationship with the green purchase intention (Ansar 2013). A key component can gain a competitive advantage by practicing marketing strategies in an environmentally friendly manner while developing ecologically safer products with recyclable and biodegradable packages while controlling environmental pollution. When comparing advertising and promotion, low investment is required for changing the package thus significant gains in brand sales can be achieved (Barber 2010). Further, literature suggested that packaging could be considered ecological depending on the degree of environmental pollution (Delia 2010).

Awareness about the several green marketing tools (e.g. eco-labelling, eco-branding, ecopackaging) helps to ensure the consumer perception towards attributes of green products. Furthermore, it helps consumers to recognize and thus make purchase decisions regarding green products (Rahbar and Wahid 2011). As the consumers and environment are interrelated, understanding consumer perception and purchase behaviour towards green products are highly significant (Delafrooz et al. 2014). However, it is very difficult to understand consumer behaviour as their needs, fashions are changing rapidly 
with the situations, and different factors may influence their purchasing behaviour. Therefore, the marketers need to examine consumer behaviour to understand their expectations, perception and decision-making during the purchasing process (Kotler 2012). However, when comparing western countries, there are far fewer studies have been carried on green marketing in the Asian context (Lee 2009) even though it should be addressed to a great extent in these countries as high population pressure challenges the environment.

Therefore, it is clear that the promotion of the application of green technologies in production and efforts to boost consumption is gaining attention globally. Accordingly, an assessment of the impact of green marketing tools on consumer purchase intention would be beneficial to marketers within the industry as well as the environment as a whole in particular in the Sri Lankan context. Hence, this study aims to look into how consumers' purchase behaviour is shaped by the green marketing tools consisting; eco-labelling, ecobranding and eco-packaging. Moreover, the study focuses to fulfill the objectives of identifying the consumer awareness and attitude towards green products and evaluating the consumer perception towards green marketing. The study will be helpful to promote green products while providing consumers more awareness of the attributes and characteristics of green products. Additionally, the present study provides a guideline for companies to develop and initiate their green and sustainable marketing strategies in an effective, profitable and accurate manner while considering consumers' perception of green marketing.

\section{Effect of demographics factors on green purchasing behaviour}

The present study intends to understand the various factors that have an impact on the attitude on green purchase behaviour of the consumers. Several past studies have been carried out to analyze the relationship between consumers' demographic factors and their purchase behaviour towards green products.
Kollmuss and Agyeman (2002) showed that pro-environmental behaviour is heavily influenced by demographic factors. Boztepe (2011) pointed out that age, gender, marital status, education and income have a moderator effect on consumer behaviour towards green purchasing. Demographic variables in terms of age, gender, income level, education level, ethnicity and occupation play a mediating role in consumers' green purchasing behaviour (Kaufmann et al. 2012). In addition, Panni (2006) identified that consumers' pro-social behaviours have been heavily influenced by demographic factors such as age, income level, education level and occupation. According to Harris et al. 2000, female, professional and younger consumers are more environmentally conscious. Gender plays an important role in environmental friendly consumers (Ruiz et al. 2001).

Witek and Kuzniar (2021) revealed that the female consumers are more enthusiastic about purchasing green products and feel more responsible for the environment than male consumers. Moreover they argued that the youngers are more skeptical about green products while old people keep more interesting on purchasing green products. There is a positive link between the individuals' financial condition and the intention to buy green items (Witek and Kuzniar 2021). According to the Paco et al. (2009), women show positive attitude towards the environment and green products and Banyte et al. (2010) identified well-educated woman who are aged between 30 and 44 as green consumers. Purchasing green product is positively correlated with consumers' income (Al-Otoum and Nimri 2015). Uusitalo and Oksanen (2004) reported that green consumers show higher socio-economic profiles. Based on such findings below hypotheses are developed.

There are significant relationships between (H1) age, (H2) gender, (H3) income level, (H4) education level, (H5) occupation, (H6) civil status and the consumers' attitude on green purchasing behavior. 


\section{MATERIALS AND METHODS}

For reasons of convenience, the study was carried out in Mapalana Magin Pahala Grama Niladari division, Matara, Sri Lanka. Consumers in the area were selected as the population for the study. A list of total of 939 residents was collected from the Grama Niladari and out of these 939 residents, 150 residents were selected through a simple random sampling technique. Primary data were collected through a pre-tested questionnaire survey.

The initial questionnaire was prepared with the help of a literature survey and pre-testing was done with 10 respondents and their responses were utilized in designing the final questionnaire. Each questionnaire item has

Table 1: Variables and measurements of the study. All the measurements were taken from five-point Likert scale.

\begin{tabular}{|c|c|c|}
\hline Variables & Statements & $\begin{array}{l}\text { KMO Val- } \\
\text { ue }\end{array}$ \\
\hline \multirow{6}{*}{$\begin{array}{c}\text { Consumer } \\
\text { awareness } \\
\text { and attitude } \\
\text { towards } \\
\text { green prod- } \\
\text { ucts }\end{array}$} & $\begin{array}{l}\text { Consumers' willingness to pay a premium price for environmental- } \\
\text { friendly green products }\end{array}$ & $0.917^{* * *}$ \\
\hline & $\begin{array}{l}\text { Consumers' awareness of the benefits of green products for their } \\
\text { health }\end{array}$ & $0.836^{* * *}$ \\
\hline & $\begin{array}{l}\text { Consumers' awareness of the benefits of green products for the envi- } \\
\text { ronment }\end{array}$ & $0.854^{* * *}$ \\
\hline & $\begin{array}{l}\text { Knowledge of the consumers' on the ability of green products to de- } \\
\text { cline the health risk }\end{array}$ & $0.868^{* * *}$ \\
\hline & $\begin{array}{l}\text { The level of awareness of green products towards the quality en- } \\
\text { hancements of the environment }\end{array}$ & $0.935^{* * *}$ \\
\hline & $\begin{array}{l}\text { Consumers' attitudes towards the government responsibility in pro- } \\
\text { moting manufacturing green products }\end{array}$ & $0.870^{* * *}$ \\
\hline \multirow{5}{*}{$\begin{array}{l}\text { Impact of } \\
\text { eco-labelling } \\
\text { on the con- } \\
\text { sumers' } \\
\text { purchase } \\
\text { behavior }\end{array}$} & Consumers' level of awareness about eco-labels & $0.785^{* * *}$ \\
\hline & Extent of keeping doubt towards the eco-labels & $0.784^{* * *}$ \\
\hline & $\begin{array}{l}\text { Influence of product information on purchasing decisions of eco- } \\
\text { labeled products }\end{array}$ & $0.814^{* * *}$ \\
\hline & Consumers' care about eco-labelling during the purchasing process & $0.716^{* * *}$ \\
\hline & $\begin{array}{l}\text { Consumers' decision in regarding purchasing only eco-labeled prod- } \\
\text { ucts }\end{array}$ & $0.737^{* * *}$ \\
\hline \multirow{5}{*}{$\begin{array}{c}\text { Impact of } \\
\text { eco- } \\
\text { branding on } \\
\text { consumers } \\
\text { purchase } \\
\text { behavior }\end{array}$} & Believes on eco-brand as a truthful marketing tool & $0.830^{* * *}$ \\
\hline & Selection of 'eco' brand as the word 'eco' sounds good & $0.859^{* * *}$ \\
\hline & Consumers' decision on purchasing eco-brand products & $0.809^{* * *}$ \\
\hline & Consumers' concern on eco brand during their purchasing & $0.767^{* * *}$ \\
\hline & Consumers' willingness to pay more for eco brand products & $0.789^{* * *}$ \\
\hline \multirow{5}{*}{$\begin{array}{l}\text { Impact of } \\
\text { eco- } \\
\text { packaging } \\
\text { on the con- } \\
\text { sumers' } \\
\text { purchase } \\
\text { behavior }\end{array}$} & Influence of package materials on purchasing decisions & $0.717^{* * *}$ \\
\hline & Consumers' concern about eco package during purchasing process & $0.761^{* * *}$ \\
\hline & Consumers' consideration of eco package as a symbol of product & $0.837^{* * *}$ \\
\hline & Favor of the consumers to purchase eco-packaged products & $0.791^{* * *}$ \\
\hline & Consumers' easy recognition of eco package by themselves & $0.775^{* * *}$ \\
\hline
\end{tabular}

\footnotetext{
${ }^{* * *}$ Bartlett's test of Sphericity $=0.000$
}

Source: Field survey, 2020 
more than 0.7 Cronbach's alpha value that verifies the higher reliability of the questionnaire (Taber 2018). The questionnaire was developed to understand the consumer profile, to assess the consumer awareness and attitude towards green products and to examine how purchase behaviour is affected by green marketing tools such as eco-labelling, eco-branding and eco-packaging. All the statements used to assess the green marketing tools were measured by using the five-point Likert scale ranging from $1=$ strongly disagree to $5=$ strongly agree. Table 1 illustrates the respective statements utilized to assess the variables of the study. The Kaiser-MeyerOlkin (KMO) measure of sampling adequacy is an index that is used to examine the appropriateness of factor analysis (Karunarathna 2017). Accordingly, the below table shows that all the statements have a KMO value of more than 0.7 , indicating the data collected is appropriate. Bartlett's test of sphericity was highly significant (0.000) which ensure the validity of the current study.

The multiple linear regression was used to identify whether there was any relationship between the main five demographic variables (age, gender, income, education, occupation and civil status) and the consumers' green purchase intention. Here, the five demographic variables were indicated as independent variables while consumers' green purchase intention was indicated as the dependent variable. Consumers' green purchase intention was computed by calculating the mean scores of all the statements that were used to assess the impact of selected green marking tools on the consumers' purchase behaviour.

When considering the appropriateness of factor analysis, the variables; age (0.698), gender (0.784), income (0.728), education (0.832), occupation (0.745), civil status (0.680) and consumer purchase intension (0.751) have KMO value more than 0.6. Further, Bartlett's test of Sphericity shows a significance level of 0.000 indicating the appropriateness of factor analysis. Hence, this validates to conduct of the multiple regression analysis for the current study.

Furthermore, the study used an independent sample t-test to assess whether there is any significant gender difference in consumer's awareness and attitude towards green products and consumer perception towards selected green marketing tools; eco-labelling, ecobranding and eco-packaging.

Secondary data were collected by using journals, research articles, newspaper articles and other websites etc. IBM SPSS version 25 was the main analytical software used in the present study. The study utilized descriptive analytical tools and inferential analytical tools such as Independent sample t-test, Multiple linear regression to analyze data.

\section{RESULTS AND DISCUSSION}

When considering the consumer profile, $55 \%$ of the respondents were female while $45 \%$ are male. When the age of the consumers takes into account, the majority of them were between 21-30 years old pertaining to $59 \%$, whereas $23 \%$ were $31-40$ years old consumers. The majority $(34 \%)$ of the consumers' earnings were between Rs. 10000 to Rs.20000 and when focusing on the occupation of the respondents, the majority were dependents that compromised $60 \%$ of the sample. Out of these respondents, the majority compromised $40 \%$ were educated up to the Ordinary Level. When considering the civil status, $61 \%$ of respondents were single (Table 2).

The first part of the analysis used the independent sample t-test to measure whether there is a significant gender difference in consumer's awareness and attitude towards green products. The study showed that there was a significant difference $(\mathrm{t}(146.9)=2.971$, $\mathrm{p}=0.003$ ) between males and females in willingness to pay a premium price for environmental-friendly green products to conserve the environment and comparatively female respondents $(\mathrm{M}=3.19, \quad \mathrm{SD}=1.152)$ agreed to pay more than male respondents $(\mathrm{M}=2.68, \quad \mathrm{SD}=0.937)$. These findings embellish the finding of the past literature. 
Table 2: Demographic profile of the sample

\begin{tabular}{|c|c|c|c|}
\hline & & $\begin{array}{c}\text { Fre- } \\
\text { quency }\end{array}$ & $\%$ \\
\hline \multirow[t]{2}{*}{ Gender } & Male & 82 & 54.7 \\
\hline & Female & 68 & 45.3 \\
\hline \multirow[t]{5}{*}{ Age } & $10-20$ & 7 & 4.7 \\
\hline & $21-30$ & 89 & 59.3 \\
\hline & $31-40$ & 34 & 22.7 \\
\hline & $41-50$ & 14 & 9.3 \\
\hline & 51-above & 6 & 4.0 \\
\hline \multirow[t]{5}{*}{ Income } & Below 10000 & 18 & 12.0 \\
\hline & $10000-20000$ & 51 & 34.0 \\
\hline & $20000-30000$ & 37 & 24.7 \\
\hline & $30000-40000$ & 24 & 16.0 \\
\hline & 40000-above & 20 & 13.3 \\
\hline \multirow{5}{*}{$\begin{array}{c}\text { Educa- } \\
\text { tional } \\
\text { level }\end{array}$} & No schooling & 0 & 0.0 \\
\hline & Up to grade 5 & 58 & 38.7 \\
\hline & $\mathrm{Up}$ to $\mathrm{O} / \mathrm{L}$ & 60 & 40.0 \\
\hline & $\mathrm{Up}$ to $\mathrm{A} / \mathrm{L}$ & 28 & 18.7 \\
\hline & $\begin{array}{l}\text { Higher Edu- } \\
\text { cation }\end{array}$ & 4 & 2.7 \\
\hline \multirow{5}{*}{$\begin{array}{l}\text { Occupa- } \\
\text { tion }\end{array}$} & Dependent & 90 & 60.0 \\
\hline & $\begin{array}{l}\text { Self } \\
\text { ployed }\end{array}$ & 18 & 12.0 \\
\hline & $\begin{array}{l}\text { Farming/ } \\
\text { Labor }\end{array}$ & 6 & 4.0 \\
\hline & $\begin{array}{l}\text { Government } \\
\text { Sector }\end{array}$ & 19 & 12.7 \\
\hline & Private Sector & 17 & 11.3 \\
\hline Civil & Married & 56 & 37.3 \\
\hline \multirow[t]{2}{*}{ Status } & Divorced & 2 & 1.3 \\
\hline & Single & 92 & 61.3 \\
\hline
\end{tabular}

Source: Field survey, 2020

Harris and his colleagues (2000) showed that women are ready to pay more as female consumers are more environmentally conscious (Harris et al. 2000). Also, consumers in Mauritius indicated that it is reasonable to pay a premium price for green products due to their ecological manner of producing and allocating more to worthy environmental causes (Juwaheer et al. 2012). As highlighted by Ottman (1998), green marketing could persuade green consumers who have an intense to pay a premium price towards a green consumption pattern.
However, gender was not significant in respondents' awareness of the benefits of green products for their health $(\mathrm{t}(146.8)=$ $0.926, p=0.356$ ) in the level of awareness of the benefits of green products for the environment $(\mathrm{t}(148)=1.216, \mathrm{p}=0.226)$, in the knowledge on the ability of green products to decline the health risk $(\mathrm{t}(146.5)=1.738, \mathrm{p}=$ 0.084 ), in the level of awareness of green products towards the quality enhancements of the environment $(\mathrm{t}(145.9)=1.724, \mathrm{p}=0.087)$ and in the attitudes towards the government responsibility in promoting manufacturing green products between males and females $(\mathrm{t}$ $(148)=-0.116, p=0.908)$.

These findings are compatible with some global research outcomes. When considering the global context, $87 \%$ of people from different countries like Canada, France, China, Germany, India, Brazil, the UK and the US have shown their concern in reducing their effect on the environment by purchasing green products (Enkvist et al 2007). In India, around $28 \%$ of the consumers may healthconscious while around $25 \%$ desire to consume environmental-friendly products in their day-to-day life (Saini 2013). In the Philippines, consumers are accountable for the environmental issues and the university students in the Philippines give fifth place to green marketing after considering the indexes of demand, price, preference of special product, and budget (Suplico 2009). Hence, the current research findings are aligned with the past literature indicating that the consumers are more cognizant about their health as well as the environment.

Irrespective of the context, the results are in line with the findings of previous scholars in their write-ups. Consumers intending to purchase green products due to their attitudes on the green concept and their awareness of green products (Mohammadian and Bakhshandeh 2014).

Multiple linear regression was done to identify the impact of five independent variables (age, gender, income, education, occupation and civil status) on consumers' 
purchase intention towards green products (Table 3).

The $p$-value functions as an indicator of significance. It is a minimum significance level that is used to determine whether reject or accept the null hypothesis (Thron and Miller 2015). Hence 0.05 is set as the threshold level of the current study and the rejection indicates a $\mathrm{p}$-value that exceeds the minimum significance level (0.05) while the acceptance reveals a $p$-value that not exceeds the minimum significance level (0.05).

The result showed that the income and the education level of the respondents were significantly contributed to the dependent variable; consumers' purchase intention, with the significance values of 0.000 and 0.001 respectively. However, age $(p=0.053)$ is marginally significant while gender $(\mathrm{p}=0.382)$, occupation $(\mathrm{p}=0.571)$ and civil status $(\mathrm{p}=0.831)$ of the respondents did not contribute significantly to the consumers' purchase intention towards the green product as the $p$ values were exceeded the significant value of 0.05 . Accordingly, $\mathrm{H} 3$ and $\mathrm{H} 4$ were accepted while $\mathrm{H} 1, \mathrm{H} 2, \mathrm{H} 5$ and $\mathrm{H} 6$ hypotheses were rejected.

The results of the multiple regression analysis revealed that the income $(\beta=0.490 ; \mathrm{t}=9.670$; $\mathrm{p}=0.000)$ and the education level $(\beta=0.264$; $\mathrm{t}=3.490 ; \mathrm{p}=0.001)$ of the respondents were positively and highly significantly contributed to the consumers' purchase intention towards the green product. It implies that the consumers whose income level is high, prefer green products for their consumption because these customer groups can afford the higher prices of green products. Additionally, the results revealed that the more educated consumers are interested in purchasing green products as they are fully conscious of the healthiness and eco-friendliness of green products. These results are aligned with past literature. Accordingly, Kaufmann et al. (2021) pointed out that the demographic variables will play an intervening role in between the green consumer behaviour index and the green consumer behaviour variables such as environmental knowledge, environmental awareness, environmental concern and attitude etc.

The adjusted $\mathrm{R}$ square value (Adjusted $\mathrm{R} 2=$ 0.773) indicated that the three factors contributed $77.3 \%$ to the dimension of consumers' purchase intention towards the green product. The validity coefficients of each measurement item in the study reveal that the measures used in this study are valid and measure what they are supposed to

Table 3: The impact of demographics factors on consumers' purchase intention towards green products

\begin{tabular}{|c|c|c|c|c|c|}
\hline \multicolumn{6}{|c|}{ Coefficients } \\
\hline \multirow[t]{3}{*}{ Model } & \multirow{2}{*}{\multicolumn{2}{|c|}{$\begin{array}{c}\text { Unstandardized Coef- } \\
\text { ficients }\end{array}$}} & \multirow{3}{*}{$\begin{array}{l}\text { Standardized } \\
\text { Coefficients } \\
\text { Beta }\end{array}$} & \multirow[t]{3}{*}{$\mathbf{t}$} & \multirow[t]{3}{*}{ Sig. } \\
\hline & & & & & \\
\hline & B & Std. Error & & & \\
\hline (Constant) & .617 & .300 & & 2.055 & $.042^{*}$ \\
\hline Age & .106 & .054 & .102 & 1.950 & $.053^{*}$ \\
\hline Gender & -.064 & .073 & -.035 & -.877 & .382 \\
\hline Income & .490 & .051 & .655 & 9.670 & $.000^{* * *}$ \\
\hline Education & .264 & .076 & .235 & 3.490 & $.001^{* * *}$ \\
\hline Occupation & -.016 & .029 & -.026 & -.568 & .571 \\
\hline Civil Status & .011 & .053 & .012 & .214 & .831 \\
\hline
\end{tabular}

\section{Dependent Variable: Consumers' Purchase Intention}

${ }^{*} \mathrm{p}<0.1, *{ }^{*} \mathrm{p}<0.05, * * * \mathrm{p}<0.01$

Source: Field survey, 2020 
measure with a high degree of support, indicating strong construct validity.

The study revealed, $82.7 \%$ of the respondents trust green marketing. The findings are in line with the study conducted by Nik Abdul Rashid (2007) that implied the knowledge level is insignificant for the consumer purchasing behaviour while the trust in ecolabels and eco-brands has a positive impact.

When considering the frequency of purchasing, the majority (52\%) of them normally purchased products that were promoted using green marketing tools in their lives as $12 \%$ of the American population actively required green products (Mintel and Stamatiou 2006). The most frequent reason behind the purchasing decision of the sample respondents was the better quality that can be assured within green products $(43.6 \%)$.

Furthermore, independent samples t-test revealed that there was a significant difference $(\mathrm{t}(148)=3.482, \mathrm{p}=0.001)$ between males and females in the repeat purchasing of products that promoted using green marketing tools while females $(\mathrm{M}=1.90, \quad \mathrm{SD}=0.713)$ repeatedly purchased green products more than their male counterparts $(\mathrm{M}=1.51$, $\mathrm{SD}=0.635$ ). This is verified by the past literature. Most of the female consumers go for green products as the women are more concerned about the environment (Harris et al. 2000).

However, there was no significant difference $(\mathrm{t}(148)=-1.513, \mathrm{p}=0.132)$ between males and females in the level of satisfaction regarding green marketing. The findings are in line with a previous study that showed an insignificant mean difference in customer satisfaction between male and female consumers. Hence, the same level of customer satisfaction regarding green marketing practices was recognized and also he pointed out that consumer satisfaction was influenced by green marketing (Sivesan et al. 2013). Nowadays, consumers are more conscious about environmental issues, the companies that promote green products can gain satisfied customers (Garg 2016).
Moreover, the independent samples t-test showed that there was no significant difference $(\mathrm{t}(148)=-1.089, \mathrm{p}=0.278)$ between males and females in willing to recommend products that promoted by green marketing to their friends and relatives. Similarly, Irawan (2012) stated that responders might discuss environmental issues and share eco-friendly products with their friends.

Independent samples t-test was further carried out to analyze the impact of eco-labelling, eco -branding and eco-packaging on consumer purchase behaviour.

\section{Impact of eco-labelling on the consumers' purchase behaviour}

The present study revealed that there was a significant gender difference $(\mathrm{t}(148)=2.180$, $p=0.031)$ in the level of awareness about ecolabel. The analysis further revealed that females $(\mathrm{M}=2.85, \mathrm{SD}=1.248)$ have more awareness than males $(\mathrm{M}=2.46, \mathrm{SD}=0.921)$. Teisl et al. (2002) discovered that eco-labels appeal to female purchasers, increasing the market share of beauty items. On the contrary, some studies conveyed a weak relationship between environmental awareness and the preference for eco-labelled products (Teisl and Roe 2005).

There was no significant difference $(\mathrm{t}$ (142.5) $=0.814, p=0.417$ ) between female and male consumers in keeping doubt towards the ecolabel. This embellishes the past literature. Rahbar and Wahid (2011) pointed out that the trust in eco-label is the hidden factor that influences green purchasing behaviour and he argued that this has not to regard to their awareness.

There was a significant difference $(\mathrm{t}(147.7)=$ $3.081, \mathrm{p}=0.002)$ in the influence of product information on purchasing decisions of ecolabelled products between males and females. The analysis revealed that females $(\mathrm{M}=3.05$, $\mathrm{SD}=1.323$ ) relied more on product information during the purchasing of ecolabelled products than males $(\mathrm{M}=2.43$, $\mathrm{SD}=1.150)$. Similarly, Juwaheer et al. (2012) demonstrated that green labelling has been 
positively associated with consumer purchasing intention. Moreover, the authors indicated that eye-catching, the sufficiency of information, readiness and the accuracy of the information on eco-labels are important elements that influencing green purchase behaviour in Mauritius.

With respect to the caring about eco-labelling during the purchasing process, independent samples t-test showed that there was no significant difference $(\mathrm{t}(148)=-0.798, \mathrm{p}$ $=0.426$ ) between males and females in this regard, and in addition, respondents were insignificant ( $\mathrm{t}(148)=-1.339, \mathrm{p}=0.183)$ in purchasing only eco-labelled products.

\section{Impact of eco-branding on the consumers' purchase behaviour}

According to the results of the independent samples t-test, there was a significant gender difference $(\mathrm{t}(148)=2.119, \mathrm{p}=0.036)$ in believing eco-brand as a truthful marketing tool. Accordingly, females believed $(\mathrm{M}=2.88$, $\mathrm{SD}=1.190)$ more than male respondents $(\mathrm{M}=2.51, \mathrm{SD}=0.837)$. This embellishes past literature. Accordingly, Juwaheer et al. (2012) documented that the consumers in Mauritius keep trust in green-branded products while Rahbar and Wahid (2011) pointed out that trust in eco-branding has become an important factor in consumers' green purchase intention. Studies have also recognized that environmental claims are more reliable if certified with green brands when comparing to neutral brands of beauty products (Banyte et al. 2010).

There was a significant difference $(\mathrm{t}(148)=$ $3.186, \mathrm{p}=0.002$ ) in preferring the 'eco' brand as the word 'eco' sounds good. The analysis further showed that the female customers $(\mathrm{M}=3.20, \mathrm{SD}=1.012)$ preferred more than male customers $\quad(\mathrm{M}=2.68, \quad \mathrm{SD}=0.969)$. Additionally, there was a significant difference $(\mathrm{t}(132.4)=2.176, \mathrm{p}=0.031)$ in favour of female and male customers to purchase eco-brand products. Female customers $(\mathrm{M}=2.90, \mathrm{SD}=1.263)$ had more favour than their male counterparts in purchasing eco-branded products $(\mathrm{M}=2.54$, $\mathrm{SD}=0.721)$. Wustenhagen and Bilharz (2006) also highlighted that the consumers act positively towards eco-branded products. Additionally, Rahbar and Wahid (2011) indicated that the eco brand is recognized as a positively significant variable towards consumer purchase behaviour.

There was a significant difference $(\mathrm{t}(144.6)=$ $2.443, \mathrm{p}=0.016$ ) between males and females in concerning about eco brand during their purchasing and female $(\mathrm{M}=3.44, \mathrm{SD}=1.156)$ concerned more than males $(\mathrm{M}=3.04$, $\mathrm{SD}=0.818$ ). In a similar vein, an earlier study supported that a significant relationship between green branding and the green purchase behaviour of consumers in Mauritius (Juwaheer et al. 2012).

Moreover, the study showed that there was no significant gender difference $(\mathrm{t}(141.5)=$ $1.637, p=0.104$ ) between males and females in willingness to pay more for eco brand products.

\section{Impact of eco-packaging on the consumers' purchase behaviour}

Independent sample t-test discovered that there was a significant gender difference $(\mathrm{t}$ $(139.2)=2.773, p=0.006)$ in the influence of package materials on purchasing decisions of products. The analysis revealed females $(\mathrm{M}=2.21, \mathrm{SD}=1.264)$ relied more on package material during the purchasing of products than males $(\mathrm{M}=1.74, \mathrm{SD}=0.803)$.

Additionally, there was a significant difference $(\mathrm{t}(147.4)=2.148, \mathrm{p}=0.033)$ between female and male customers concerning about eco package of the product during their purchasing process. Female customers $(\mathrm{M}=2.51, \mathrm{SD}=1.220)$ had more concern than their male counterparts $(\mathrm{M}=2.13$, $\mathrm{SD}=0.945$ ). Biodegradability and the ability to reuse and recycle can be indicated as the main features of eco package thus have some impact on the green consumption pattern of consumers (Juwaheer et al. 2012).

In addition, there was a significant gender difference $(\mathrm{t}(143.2)=3.789, \mathrm{p}=0.000)$ in considering eco package as a symbol of product reliability while the female $(\mathrm{M}=2.62$, $\mathrm{SD}=1.385)$ were considered more than male 
respondents $(\mathrm{M}=1.90, \mathrm{SD}=0.949)$. Further results showed that there was a significant difference $(\mathrm{t}(146.6)=3.002, \mathrm{p}=0.003)$ in the favor of purchasing eco-packaged products between males and females and females $(\mathrm{M}=2.66, \mathrm{SD}=1.433)$ had more favour than their male counterparts $(\mathrm{M}=1.99, \mathrm{SD}=1.310)$. Research conducted in Mauritius also produced inconclusive evidence that green packaging is an essential element impacting consumer purchasing behaviour with a positive correlation and highlighted that ecopackaging is an effective marketing tool to promote green purchasing patterns among Mauritius customers (Juwaheer et al. 2012).

There was no significant difference ( $\mathrm{t}$ (147.1) $=0.817, \mathrm{p}=0.415)$ between males and females in easy recognition of eco package by themselves.

The present findings ramified the past findings that the green marketing have a positive and meaningful impact on consumer's green purchase behavior (Kordshouli and Bouzanjani 2012). It is assumed that the customers will view the "greenness" of a product or service as a benefit of green marketing and thus make their purchasing decisions. Consumers are more focused on maintaining a cleaner and greener environment hence willing to pay more in green marketing (Mahmoud et al. 2017) and there is a significant positive relationship between green promotion and consumers' green purchase intention. Moreover, marketers should get the benefit from green branding, packaging and labelling to build an upsurge demand (Juwaheer et al. 2012).

\section{Theoretical Implications}

This present study provided evidence that consumer's perceived environmental value should be taken into consideration when conducting a targeted marketing campaign. The findings verified the signaling theory approach to green marketing as it indicates a significant gender difference in consumer's willingness to pay a premium price for environmental-friendly green products to conserve the environment. As indicated by the signaling theory, green items can have a flagging benefit. This benefit goes about as an impetus for clients to pay a premium for harmless to the ecosystem items that can leave even out their value inconvenience (Berger 2019). In light of the theory, environmental concern assumes a significant part in promoting green products, and it conveys the possibility to impact customers, purchase behaviour because of passionate excitement, which can prompt green purchase intention (Liao et al. 2020). Therefore, it is a powerful theoretical implication for companies to re-structuring their existing marketing policies towards greener marketing tools while considering gender and other attributes in particular.

\section{Managerial Implications}

Several managerial implications can be suggested from the present study. To start with, the findings recommended that the marketers should attempt to take out the consumers' attention towards products utilizing infomercials and green marketing tools such as eco-labelling, eco-packaging and eco-branding, as this could expand the buyer's purchase intention towards green items. Marketing managers should focus on the gender of the consumer when marketing green products, as the present study shows significant gender differences. It also positively impacts the level of environmental concern among consumers, promising them an eco-friendly living. Besides, the results can help the marketers to recognize that customers' income and education level were revealed to affect consumer's purchase intention thus it will help them to implement better marketing plans and marketing strategies in the future while considering these attributes. Moreover, the findings of the study indicated that several statistically significant gender differences in eco-labelling, ecobranding and eco-packaging phenomena. Accordingly, it will also become practical tools and beneficial for the marketers and executives in the industry to promote green products while implementing gender-based strategies on eco-labelling, eco-branding and eco-packaging. Additionally, the current investigation likewise conveys suggestions for 
policymakers, who could foster advertising projects to improve green purchase behavior. They should focus on that to inspire consumers' purchase intention while paying attention the environmental concerns. For instance, government authorities can make narrative motives to persuade marketers regarding the significance and go up against the pragmatic ecological issues, just as giving important proposals and rules to follow.

\section{CONCLUSIONS}

The study on the impact of green marketing tools on consumer purchase behaviour shows significant gender differences with respect to eco purchase intention. Female consumers were willing to pay a premium price for green products to conserve the environment. Interestingly, respondents' income and education level were positively and highly significantly contributed to the consumers' purchase intention towards green products. Most importantly, the majority of the respondents $(82.7 \%)$ trust green marketing and they normally purchased (52\%) products that were promoted using green marketing tools due to their better quality $(43.6 \%)$ while female consumers showed a repeat purchasing of the products that were promoted using green marketing tools than males. Moreover, consumers were satisfied and willing to recommend products promoted by green marketing for their friends and relatives regardless of gender.

In addition, females were more aware, more influential of product information, and relied more on product information during the purchasing of eco-labelled products than their male counterparts. Female believed eco-brand as a truthful marketing tool and they preferred 'eco' brand as the word 'eco' sounds good. In addition, female consumers were more concerned about eco brand and they had more favour to purchase eco brand products than male consumers. The results concluded that the females relied more on package material and were concerned about eco package during their purchasing process. Besides, females considered eco packages as a symbol of product reliability and they showed more favours in purchasing eco-packaged products than their male counterparts.
It is recommended that Asian marketers have to take into account the consumers' perception of green products and the impact of green marketing tools on their purchase behaviour to enhance the product performance and attract potential customers.

\section{AUTHOR CONTRIBUTION}

SDMM and SGC designed the present study on "How Green Marketing Tools Shape Consumer Purchase Behavior" and performed the pre-tested questionnaire survey. The data were collected and analyzed by SDMM and wrote the paper with input from the co-author, SGC. Both SDMM and SGC critically revised the manuscript.

\section{References}

Al-Otoum FJ and Nimri RS 2015 Antecedents of Environmental Buying Behavior: Case of the Jordanian Market. International Journal of Business and Management. 10(9): 240-250.

Ansar N 2013 Impact of green marketing on consumer purchase intention. Mediterranean Journal of Social Sciences, 4(11): 650-655. <https:// doi.org/10.5901/ mjss.2013.v4n11p650>

Banyte J, Brazioniene L and Gadeikene 2010 Investigation of green consumer profile: a case of Lithuanian market of eco-friendly food products. Economics and Management. 15 :374-384.

Barber N 2010 Green wine packaging: targeting environmental consumers. International Journal of Wine Business Research. 22(4):423-44.

Berger J 2019 Signaling can increase consumers' willingness to pay for green products. Theoretical model and experimental evidence. Journal of consumer behaviour. 18(3): 233-246. https://doi.org/10.1002/cb.1760

Bourgeois JC and Barnes JG 1979 Viability and profile of the consumerist segment. Journal of Consumer Research. 5: 217-227.

Boztepe A 2011 Green Marketing and its impact on consumer behavior. Europian Journal of Business and Management. 3(4): 375-384. 
Delafrooz N, Taleghani M and Nouri B 2014 Effect of green marketing on consumer purchase behavior. QScience Connect, 1(5): 2-9. https:// doi.org/10.5339/connect.2014.5

Delia D 2010 Review concerning the functions of packaging. viewed 15th October 2020: <www.faqs.org/ periodicals/201001/2002253261.html>

Enkvist, Per-Anders, Nauclér T and Rosander J 2007 A Cost Curve for Greenhouse Gas Reduction. The McKinsey Quarterly. 1: 35-45.

Farzin A, Yousefi S, Amieheidari S and Noruzi A 2020 Effect of green marketing instruments and behavior processes of consumers on purchase and use of e-books. Webology. 17 (1):202-215. $<$ https:// doi.org/10.14704/WEB/V17I1/A217>

Garg C 2016 The Impact of Green Marketing on Consumer Satisfaction and Environmental safety. International Research Journal of Management Science \& Technology. 7(2): 77-79.

Harris B., Burress D and Eicher S 2000 Demand for local and organic product: a brief review of literature. Kansas: University of Kansas Institute for Public Policy and Business Research. viewed 15th October 2020: <http:// quickfacts.census.gov/qfd/ states/29000.html>

Hustad TP and Pessemier EA 1973 Will the real consumer activists please stand up: An examination of consumers' opinions about marketing practices? Journal of Marketing Research. 10: 319-324.

Irawan R and Darmayanti D 2012 The influence factors of green purchasing behavior: A study of university students in Jakarta. Proceedings of the 6th Asian Business Research Conference. Bangkok, Thailand. 8-10 April 2012: 1-11

Juwaheer TD, Pudaruth S and Noyaux MME 2012 Analysing the impact of green marketing strategies on consumer purchasing patterns in Mauritius. World Journal of Entrepreneurship, Management and Sustainable
Development. 8(1): 36-59. <https:// doi.org/10.1108/20425961211221615 $>$

Karunarathna WRAD, Naotunna SS and Sachitra KMV 2017 Factors Affect to Green Products Purchase Behavior of Young Educated Consumers in Sri Lanka. Journal of Scientific Research \& Reports. 13(2): 1-12.

Kaufmann HR, Panni MFAK and Orphanidou Y 2012 Factors Affecting Consumers' Green Purchasing Behavior: An Integrated Conceptual Framework. Amfiteatru Economic Journal, The Bucharest University of Economic Studies, Bucharest. 14(31):50-69.

Kollmuss A and Agyeman J 2002 Mind the gap: why do people act environmentally and what are the barriers to pro-environmental behavior?. Environmental Education Research. 8(3):239-260.

Kordshouli HR and Bouzanjani AA 2012 Investigating the mixed effect of green marketing on consumers' decision to green purchasing (consumers of Pegah Dairy Company's products in Shiraz). Journal of New Marketing Research. 2 (2): 165-180.

Kotler P 2012 Marketing Management, millenium edition: Custom Edition for University of Phoenix. (10 ed.). New Jersey: Pearson Custom Publishing.

Lee K 2009 Gender differences in hongkong adolescent consumer' green purchase behaviour. Journal of Consumer Marketing. 26 (2): 87- 96.

Liao YK, Wu WY and Pham TT 2020 Examining the moderating effects of green marketing and green psychological benefits on customers' green attitude, value and purchase intention. Sustainability (Switzerland). 12(18): $\quad 7461 . \quad<$ https:// doi.org/10.3390/SU12187461>

Mahmoud TO, Ibrahim SB, Ali AH and Bleady A 2017 The Influence of Green Marketing Mix on Purchase Intention: The Mediation Role of Environmental Knowledge. International Journal of Scientific \& Engineering Research. 8(9):1040- 
1048. < < <ttps://doi.org/10.14299/ ijser.2017.09.006>

Mintel R and Stamatiou E 2006 Green RoofsA 21 st Century Solution to the Urban Challenges of Green Space, Air Pollution, Flooding \& Energy Conservation, WSEAS International Conference Vouliagmeni, Greece. Journal WSEAS Transactions on Energy, Environment, Ecosystems and Sustainable Development. 2(6): 909918.

Mohammadian M and Bakhshandeh G 2014 Investigation of influential factors on consumers' attitude and green purchase intention. Management Studies in Development and Evolution. 23(3):39-68.

Nik Abdul Rashid NR 2007 Employee involvement in ems/iso14001and its spillover effect in creating consumer environmentally responsible behavior. Unpublished doctoral dissertation, University Sains Malaysia, Malaysia.

Ottman J 1998 Green Marketing: Opportunity for Innovation. (Lincolnwood [Chicago]:NTC Business Books) NTC -McGraw-Hill, New York, NY

Paco AMF, Raposo MLB and Filho, WL 2009 Identifying the green consumer: a segmentation study. Journal of Targeting, Measurement and Analysis for Marketing, 17(1) : 17-25.

Panni MFAK 2006 The Effect of Consumerism towards customer attitudinal behavior in food industry in Malaysia, Unpublished M.Phil thesis, Multimedia University.

Peattie K 2001 Towards sustainability: the third age of green marketing. The Marketing Review. 2(2):129-146.

Rahbar E and Wahid NA 2011 Investigation of green marketing tools' effect on consumers' purchase behavior. Business Strategy Series. 12(2):73-83. $<$ https:// doi.org/10.1108/17515631111114877 $>$

Rahman ASMS, Barua A, Hoque R and Zahir R 2017 Influence of Green Marketing on Consumer Behavior: A Realistic Study on Bangladesh. Global Journal of Management and Business Research: E Marketing. 17(1): 1-9.

Roy H 2013 Effect of Green Marketing on Consumer Behaviour - a Study With Particular Reference To West Bengal ( India ). International Journal of Behavioural Social and Movement Sciences. 2(1):44-55.

Ruiz S, Arcas N and Cuestas P 2001 Consumer attitudes towards ecological agrarian fruits and vegetables in Spain. A segmentation approach. Acta Horiculturae. 559: 681-686.

Saini B 2013 Green Marketing and its impact on consumer behavior. Europian Journal of Business and Management. 2(12): 61-64.

Sharma NK and Kushwaha GS 2019 Ecolabels: A tool for green marketing or just a blind mirror for consumers. Electronic Green Journal. 1(42). $<$ https://doi.org/10.5070/ G314233710>

Simi TB 2009 Eco-labels: Trade Barriers or Trade Facilitators. CUTS Centre for International Trade, Economics \& Environment-Discussion Paper. 1.

Sivesan S, Achchuthan S and Umanakenan R 2013 Special Reference to Leather Goods Green Marketing Practices and Customer. 13(3): 51-59

Suplico LT 2009 Impact of green marketing on the students' purchase decision. Journal of International Business Research. 8(2):71-81

Taber K 2018 The Use of Cronbach's Alpha When Developing and Reporting Research Instruments in Science Education, Research in Science Education. 48(1):1-24

Teisl MF and Roe B 2005 Evaluating the factors that impact the effectiveness of eco-labelling programmes, in Krarup, S. and Russel, C.S. (Eds), Environment, Information and Consumer Behaviour, Edward Elgar, Cheltenham: 65-90.

Teisl MF, Roe B and Hicks RL 2002 Can ecolabels tune a market? Evidence from dolphin-safe labelling. Journal of Environmental Economics and Management. 43(3) :339-359. 
The Eco-Safe Blog 2020 Eco-Labelling: Objectives \& Benefits. viewed 15th October 2020: <https:// ecosafesibm.wordpress.com/2009/07/1 0/eco-labelling-objectives-benefits/>

Thron C and Miller V 2015 Persistent Confusions about Hypothesis Testing in the Social Sciences. Socail Sciences. 4: 361-372; doi:10.3390/ socsci4020361

Uusitalo O and Oksanen R 2004 Ethical consumerism-a view from Finland. International Journal of Consumer Studies. 28(3): 214-221.

Witek L and Kuzniar W 2021 Green Marketing: The Effectiveness of Socio -Demographic Variables for Explaining Green Purchases Behavior in Emerging Markets. European Research Studies Journal. 24 (2) : 1070-1080

Global Ecolabelling Network 2020 What is Ecolabelling. viewed 15 th October 2020: $\quad<$ https:// www.globalecolabelling.net/what-iseco-labelling/>

Wustenhagen R and Bilharz M 2006 Green energy market development in Germany: effective public policy and emerging customer demand, Energy Policy.34:1681-96. 